\title{
Akuntabilitas Publik Anggota DPD RI Dalam Menindaklanjuti Aspirasi Daerah (Studi Kasus Layanan Kesehatan Gratis Masyarakat Banten)
}

\author{
Nurul Agustin ${ }^{1}$, Arief Maulana ${ }^{2}$ \\ ${ }^{1}$ Peneliti di Pusat Kajian Daerah dan Anggaran, Setjen Dewan Perwakilan Daerah RI \\ ${ }^{2}$ Peneliti di Pusat Kajian Daerah dan Anggaran, Setjen Dewan Perwakilan Daerah RI
}

\section{ARTICLE INFORMATION}

Received: July 17, 2020

Revised: October 29, 2020

Accepted: November 01, 2020

Available online: November 13, 2020

\section{KEYWORDS}

Accountability, Regional Aspirations, The House of Regional Representative.

CORRESPONDENCE

Phone: +6285399542628

E-mail: maulana arief@ymail.com

\begin{abstract}
A B S T R A C T
In the Indonesian constitution, the Regional Representative Council of the Republic of Indonesia (DPD RI) is one of the representative institutions that has the task of fighting for regional interests in political decision making. One form of public accountability for members of the DPD RI is to follow up regional aspirations. The problem of the free health service program in Banten Province, which is considered to be in conflict with Law Number 24 of 2011 concerning the Social Security Organizing Agency, examines the quality of the representative functions of DPD RI members as people's representatives in the regional context with the orientation of regional interests. This study aims to explain the roles and obligations of DPD RI members in following up on their regional aspirations. This research used a qualitative method with a case study approach. The results of this study indicate that the success of DPD RI members' accountability depends on their ability to establish good relationships with executive institutions and local governments. The accountability of DPD RI members is proven in this case because the Ministry of Health is now supporting the Banten Provincial Government's policy to fill a vacancy before all Banten people are registered as National Health Insurance participants.
\end{abstract}

\section{PENDAHULUAN}

Eksistensi lembaga perwakilan yang merepresentasikan kedaerahan di level pusat memiliki peran yang sangat penting dalam sistem ketatanegaran Republik Indonesia. Hal ini dikarenakan Indonesia tidak hanya memiliki rakyat yang berada di level pusat tetapi juga di level daerah (Manan, 1992). Dewan Perwakilan Daerah Republik Indonesia (DPD RI) merupakan bentuk perwujudan lembaga perwakilan daerah di Indonesia. Sebagaimana Visi DPD RI itu sendiri untuk menjadi parlemen yang kuat dan aspiratif demi memperjuangkan kepentingan daerah dalam wadah NKRI, maka DPD RI menjadi wakil daerah untuk menyerap, menghimpun dan menindaklanjuti aspirasi masyarakat dan daerah dalam pengambilan kebijakan di level nasional.

DPD RI sebagai lembaga perwakilan daerah merupakan sumber daya politik yang sangat penting dalam rangka mendorong kemajuan daerah melalui konsolidasi politik bersama-sama DPR, DPRD, dan Pemerintah. Kehadiran DPD RI merupakan tuntutan dari perwujudan demokratisasi guna meningkatkan semangat dan kapasitas partisipasi daerah dalam kehidupan nasional, memenuhi rasa keadilan masyarakat di daerah, serta untuk memperkuat Negara Kesatuan Republik Indonesia.

Sebagai lembaga legislatif, DPD RI menghadapi tantangan besar untuk meningkatkan peran anggotanya sebagai representasi daerah di tingkat nasional. Oleh karena itu, salah satu kewajiban anggota DPD RI adalah menyerap, menghimpun, dan menindaklanjuti aspirasi masyarakat dan daerah. Sebagai instrumen untuk memperjuangkan kepentingan daerah, maka penyerapan aspirasi merupakan kegiatan Anggota DPD RI yang paling penting. Namun, dari berbagai pemberitaan di media massa serta berbagai temuan dari studi yang telah dilakukan sebelumnya, banyak kritikan terhadap anggota legislatif yaitu menyangkut kualitas representasi mereka dalam menyuarakan kepentingan dan aspirasi masyarakat serta mewujudkannya dalam berbagai tindakan maupun kebijakan yang dihasilkan.

Salah satu permasalahan terkait isu-isu di daerah yang menjadi isu nasional dan kemudian diperjuangkan oleh Anggota DPD RI sebagai wujud pelaksanaan tugas keterwakilan daerah ditingkat pusat, permasalahan program layanan kesehatan gratis Provinsi Banten yang dinilai oleh Pemerintah Pusat bertentangan dengan UU Nomor 24 tahun 2011 tentang Badan Penyelenggara Jaminan Sosial (BPJS) merupakan suatu hal yang penting untuk dikaji lebih lanjut (Puskada DPD RI, 2018).

Sebagaimana diketahui, pemerintah memiliki suatu program jaminan kesehatan bernama Jaminan Kesehatan Nasional (JKN) yang dikelola oleh Badan Penyelenggara Jaminan Sosial Kesehatan (BPJS Kesehatan). Oleh karena itu, masyarakat didorong agar proaktif mendaftarkan diri sebagai anggota JKN dengan syarat dan ketentuan berlaku sesuai fasilitas kesehatan yang diinginkan (Wulanadary et al., 2019). Akan tetapi, permasalahan mulai muncul saat masyarakat yang memerlukan layanan kesehatan tidak sepenuhnya dapat dilayani oleh BPJS Kesehatan karena adanya aturan pembatasan dari BPJS Kesehatan itu sendiri. Alasan pembatasan tersebut dungkapkan karena kemampuan keuangan BPJS Kesehatan 
yang defisit sehingga mengakibatkan beberapa layanan kesehatan untuk peserta BPJS Kesehatan terpaksa "dikurangi" agar sesuai dengan kemampuan keuangan BPJS Kesehatan (Triwahyuni et al., 2020; Victoria, 2019). Padahal sebagaimana diketahui bersama, peserta BPJS Kesehatan mayoritas merupakan masyarakat menengah ke bawah yang mempunyai anggaran belanja kesehatan yang cukup terbatas.

Untuk mengatasi masalah tersebut, Pemerintah Provinsi Banten berinisiatif membuat program layanan kesehatan gratis yang tidak terintegrasi dengan BPJS Kesehatan. Akan tetapi, program tersebut mendapat koreksi dari pemerintah pusat (dalam hal ini Kementerian Kesehatan RI) dengan alasan bertentangan dengan peraturan perundang-undangan yang berlaku. Dalam konteks permasalahan ini, Anggota DPD RI Provinsi Banten menggunakan hak konstitusionalnya pada kegiatan penyerapan aspirasi di Provinsi Banten untuk menemukan akar permasalahan terkait dengan program layanan kesehatan gratis untuk warga miskin tersebut.

Berdasarkan latar belakang dan problematika tersebut, tulisan ini hendak menjelaskan peran atau fungsi Anggota DPD RI dalam menindaklanjuti aspirasi daerahnya, dalam hal ini terkait permasalahan program layanan kesehatan gratis masyarakat Provinsi Banten dalam bentuk sinergi pusat dan daerah. Tulisan ini juga menjelaskan fungsi anggota DPD RI dan kewajibannya menyerap aspirasi daerah. Tulisan ini diharapkan dapat bermanfaat untuk memberi penjelasan kepada masyarakat terkait program layanan kesehatan gratis di daerah dan juga diharapkan dapat menjadi model untuk Anggota DPD RI dalam melaksanakan tugas, fungsi dan kewajibannya dalam menyuarakan aspirasi daerah sebagai bentuk akuntabilitas publik.

Orisinalitas kajian yang penulis lakukan ini terletak pada sudut pandang atau perspektifnya. Jika dibandingkan dengan kajian-kajian lain yang terkait akuntabilitas publik anggota parlemen, kajian ini tidak hanya mencari bagaimana urgensi kajian atau analisis belaka dalam proses akuntabilitas publik saja. Lebih dari itu, kajian ini merumuskan bagaimana peran ideal anggota parlemen (dalam hal ini Anggota DPD RI) agar berhasil dalam menindaklanjuti aspirasi dari daerahnya. Oleh karena itu, kajian ini dirasakan cukup signifikan untuk dilakukan, baik untuk dunia akademis maupun untuk DPD RI atau lembaga perwakilan lain di tingkat pusat atau daerah.

\section{Teori Perwakilan}

Salah satu karakteristik penting yang ada di berbagai negara tentang sistem pemerintahan yang demokratis adalah adanya wakil rakyat. Setiap warga negara berhak memilih dan mempercayakan beberapa orang dari mereka untuk memegang kendali pemerintahan. John Stuart Mill, berpendapat bahwa karena tidak semua orang bisa berpartisipasi dalam semua urusan pemerintahan secara langsung, maka jenis ideal dari pemerintahan yang baik haruslah pemerintahan yang bersistem perwakilan (Dahl, 1989).

Pada umumnya, sistem pemerintahan perwakilan lebih digunakan oleh komunitas modern. Semakin modern suatu komunitas, maka semakin kompleks pula mekanisme representasi yang digunakannya. Andrew Heywood mengatakan bahwa representasi berbeda dengan demokrasi, karena representasi mengakui perbedaan antara pemerintah dan yang diperintah. Sedangkan demokrasi bercita-cita untuk menghilangkan perbedaan posisi dan membangun pemerintahan sendiri yang lebih merakyat (Heywood, 2000).

97 https://doi.org/10.35308/jpp.v6i2.2400
Sejalan dengan perubahan geografis dan demografis dalam sejarah negara modern, persoalan representasi politik menjadi menarik perhatian berbagai kalangan dari lapisan masyaran. Akibatnya, muncullah konsep representasi yang menjadikan lembaga perwakilan sebagai sebuah media untuk menghubungkan pemerintah (eksektif) dengan masyarakat (Pahlevi, 2014).

Merujuk pada pendapat yang dikemukakan oleh(Sanit, 1995), yang menjelaskan: "Peran perwakilan dari badan legislatif pada dasarnya berkaitan dengan pertanyaan tentang hubungan antara entitas tersebut, ada anggota legislatif, dengan anggota masyarakat yang mewakili mereka secara individu, kelompok atau secara keseluruhan. sebuah visi yang melihat hubungan adalah salah satu isu inti dalam kehidupan sistem politik pada umumnya, dan dalam proses legislatif pada khususnya" (Hertanto, 2018; Sanit, 1995).

Oleh karena itu, representasi/perwakilan politik dapat diartikan sebagai wakil masyarakat untuk memperjuangangkan kepentingan masyarakat dalam setiap proses politik (Pitkin, 1967; Reiza Macella, 2020). Tingakatan atau level representasi juga ditentukan oleh sistem politik yang berlaku di suatu masyarakat. Adanya wakil masyarakat mengindikasikan ada sesuatu yang diwakilinya. Dalam hal ini, Paiman Napitupulu mengemukakan bahwa proses perwakilan memuat dua hal penting, yakni representasi dari sebuah kepentingan untuk diperjuangkan dan perwakilan dari suatu pendapat untuk disuarakan (Napitupulu, 2007; Trisna \& Marefanda, 2018).

DPD RI sebagai lembaga legislatif mempunyai peran sebagai representasi politik yang menampung dan menindaklanjuti asprasi masyarakat dan daerah di tingkat nasional. Peran Anggota DPD RI diperlukan agar daerah memiliki perwakilan tetap yang terus mengakomodasi kepentingan daerah dalam setiap pengambilan kebijakan oleh pemerintah pusat. Peran Anggota DPD RI ini dapat dikaitkan dengan teori power struggle di mana power adalah suatu cara yang digunakan untuk mempengaruhi pihak lain (Morgenthau, 1973). Dengan kata lain, kehadirannya diharapkan dapat memberi manfaat bagi masyarakat untuk meningkatkan kesejahteraan dan kemajuan daerah di seluruh tanah air Indonesia.

\section{Konsep Akuntabilitas}

Akuntabilitas berasal dari kosakata Latin yaitu accomptare (mempertanggungjawabkan), dimana accomptare sendiri berakar dari kata dasar computare (memperhitungkan). Akuntabilitas merupakan suatu konsep yang memuat kewajiaban bagi lembaga publik untuk lebih memfokuskan pada pertanggungjawaban horizontal kepada masyarakat (selaku yang diwakilinya), bukan hanya pertanggungjawaban vertikal kepada otoritas yang lebih tinggi (Turner \& Hulme, 1997). Mardiasmo berpendapat bahwa akuntabilitas merupakan bentuk keharusan untuk bertanggung jawab atas keberhasilan dan/atau ketidakberhasilan pelaksanaan sebuah misi lembaga dalam mencapai tujuan yang telah ditentukan secara berkala (Mardiasmo, 2006). Dalam kajian ini, yang dimaksud dengan konsep akuntabilitas adalah pertanggungjawaban Anggota-Anggota DPD RI sebagai wakil rakyat dan daerah dalam kegiatan penyerapan aspirasi.

Menurut pendapat S. Rasul, akuntabilitas merupakan pemberian jawaban kepada otoritas yang lebih tinggi atas tindakan seseorang/sekelompok orang terhadap masyarakat. 
Oleh karena itu, pertanggungjawaban kepada masyarakat umum (publik), sering disebut dengan akuntabilitas publik (Rasul, 2003). Jika dikaitkan dengan kajian ini, berdasarkan pendapat ini, maka otoritas yang lebih tinggi dari wakil rakyat adalah rakyat itu sendiri.

Pasal 7 UU Nomor 28 Tahun 1999 menyatakan bahwa "Asas akuntabilitas adalah asas yang menentukan tiap-tiap kegiatan dan hasil dari kegiatan penyelenggaraan negara harus dipertanggungjawabkan kepada rakyat sebagai pemegang kedaulatan tertinggi sesuai dengan ketentuan peraturan perundang-undangan yang berlaku. Secara umum, terdapat empat jenis akuntabilitas yaitu (Tjokroamidjojo, 1984):

a. Akuntabilitas politik dari pemerintah melalui lembaga perwakilan.

b. Akuntabilitas keuangan melalui pengawasan Badan Pemeriksa Keuangan.

c. Akuntabilitas hukum dalam bentuk reformasi hukum.

d. Akuntabilitas ekonomi dalam bentuk likuiditas dan kepailitan dalam suatu pemerintahan yang demokratis bertanggungjawab pada rakyat melaui sistem perwakilan.

Dari penjelasan tersebut, dapat dikatakan bahwa penyerapan aspirasi oleh Anggota DPD RI adalah salah satu bentuk akuntabilitas publik dalam penyelenggaraan pemerintahan (akuntabilitas parlemen). Konsep akuntabilitas parlemen didasarkan pada premis bahwa parlemen, sebagai organ perwakilan rakyat, memiliki tugas untuk mengawasi aktivitas eksekutif melalui sejumlah langkah. Hal ini juga terkait erat dengan akuntabilitas institusional anggota parlemen, baik secara kolektif maupun individual.

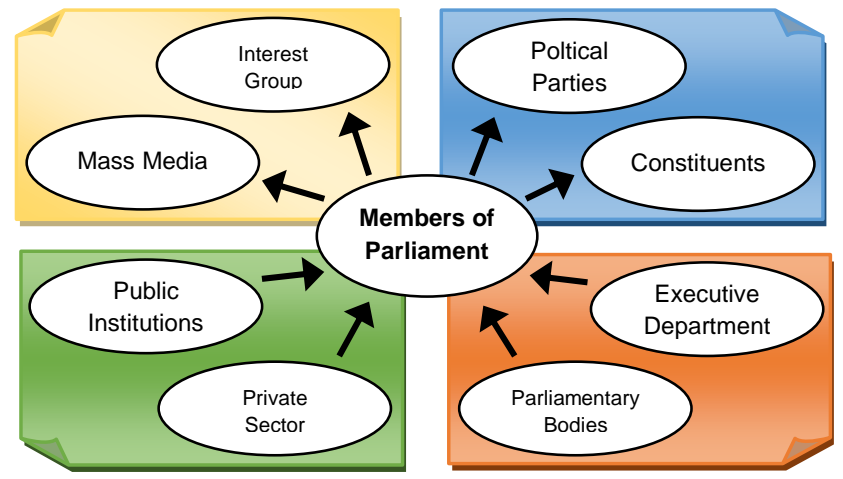

Gambar 1. Lingkungan Akuntabilitas Anggota Parlemen

Gambar 1 menunjukkan model teoretis dari lingkungan akuntabilitas anggota parlemen yang diusulkan oleh J. Sabourin (2002). Model ini menjelaskan hubungan akuntabilitas yang mungkin berbeda yang mencirikan interaksi dan aktivitas sehari-hari anggota dewan/parlemen. Model tersebut menjelaskan bahwa garis bisnis mengacu pada area aktivitas misalnya anggota bekerja di komite/komisi. Hubungan pertama adalah pengawasan eksekutif. Pemerintah bertanggung jawab kepada legislatif, anggota memiliki mandat untuk menuntut akuntabilitas. Selanjutnya adalah hubungan akuntabilitas dengan sektor swasta, yang menunjukkan bagaimana anggota melalui undang-undang yang berlaku, berdebat tentang isu-isu kebijakan dan isu-isu yang berkaitan dengan penciptaan lingkungan, mendorong akuntabilitas di pihak sektor swasta. Hubungan lain adalah dengan media dan dengan kelompokkelompok kepentingan. Meskipun anggota tidak menjawab kelompok media, akuntabilitas anggota untuk kelompokkelompok ini berhubungan dengan citra dan sikap anggota, yang memainkan peran kunci dengan pemilih. Jawaban utama dari anggota dikatakan dapat ditemukan di kotak suara. Pemilihan harus dimenangkan dan pertanggungjawaban pun dimulai dan diakhiri di daerah pemilihan.

\section{METODE}

Metode yang digunakan dalam kajian ini adalah metode kualitatif dengan pendekatan studi kasus. Kajian ini menggunakan dua jenis data, yaitu data primer dan data sekunder. Data primer diperoleh dengan memilih informan yang dianggap paham terhadap masalah kajian (purpossive sampling). Dengan teknik ini, informan yang dipilih adalah informan yang dianggap memiliki peran strategis dan memiliki otoritas terkait kebijakan (Fuad, 2017). Untuk kebutuhan data tersebut, maka informan yang diwawancarai antara lain: Anggota DPD RI Provinsi Banten, Pimpinan DPD RI, Sekretaris Daerah Provinsi Banten, Kepala Dinas Kesehatan Provinsi Banten, dan beberapa Pejabat terkait di Ditjen Pelayanan Kesehatan Kementerian Kesehatan RI. Sedangkan data sekunder diperoleh dengan cara menelaah dokumen-dokumen penting terkait serta mnghimpun data-data yang diperlukan dari Pemerintah Provinsi Banten, BPJS Kesehatan serta Kementerian Kesehatan.

Kajian ini menggunakan teknik keabsahan data guna menjamin objektivitas penafsiran data. Keabsahan data merupakan hal penting untuk mengukur sejauh mana interpretasi yang dilakukan oleh peneliti dapat dipercaya. Kajian ini menggunakan teknik validasi data sebagaimana yang dikonsepkan oleh John (Cresswell, 2009). Selanjutnya, dalam tahapan akhir penulis mendiskusikan laporan kajian ini dengan sesama rekan peneliti dan analis kebijakan di Sekertariat Jenderal DPD RI.

\section{HASIL DAN PEMBAHASAN Akuntabilitas Anggota DPD RI}

Dalam konteks DPD RI, akuntabilitas dapat dimaknai dengan pertanggungjawaban dengan menciptakan pengawasan terhadap kekuasaan pada berbagai lembaga pemerintah, sehingga mengurangi penumpukkan kekuasaan sekaligus menciptakan kondisi saling mengawasi. DPD RI dalam sistem demokrasi perwakilan modern dapat dianalisis sebagai sebuah rangkaian hubungan antara pemberi mandat dan penerima mandat (principal-agent relations). Dalam rangkaian hubungan ini, warga negara merupakan "the primary principal in a democracy" yang menyerahkan kedaulatannya kepada wakil-wakil mereka untuk menyuarakan dan mewujudkan aspirasi dan kepentingan mereka. Dari perspektif ini, maka dapat dikatakan bahwa Anggota DPD RI merupakan juga merupakan agent, yang dipilih oleh konstituen (sebagai principal) untuk membuat kebijakan dan mengawasi pelaksanaan kebijakan itu oleh pemerintah. Oleh karena fungsinya yang strategis tersebut dan menerima mandat dari konstituen, maka menjadi penting anggota DPD RI juga diminta pertanggujawaban oleh konstituen atas kekuasaan yang telah diamanatkan kepada mereka.

Dalam perspektif demokrasi liberal, akuntabilitas publik merupakan mekanisme penting untuk menjamin para penerima mandat dapat melaksanakan tugasnya dalam memberikan pelayanan publik, memberikan respon atas tuntutan dan aspirasi publik, memelihara netralitas dan kualitas perwakilan, serta menjamin persamaan dan keadilan (Haque, 2000). Oleh 
karena itu, akuntabilitas publik merupakan peluang para Anggota DPD RI untuk mempertanggungjawabkan kiprah dan segala tanggung jawab kepada daerahnya. Salah satu bentuk akuntabilitas publik adalah dengan menindaklanjuti aspirasi.

Adapun faktor dalam proses sebuah hubungan sosial sebagai sebuah praktik dari akuntabilitas publik agar benarbenar berkualitas, Anggota DPD RI memiliki rasa berkewajiban untuk menjelaskan kepada publik dan menjustifikasi tindakantindakannya dalam sebuah forum khusus. Secara khusus, kualifikasi ini mengandung paling tidak 5 elemen, yaitu:

a. Akses publik atas proses pertanggungjawaban, bukan proses yang sifatnya internal dan tertutup;

b. Penjelasan dan justifikasi atas tindakan bukan kampanye, atau informasi kepada masayarakat umum;

c. Penjelasan harus disampaikan dalam forum khusus bukan forum yang asal-asalan (random);

d. Aktor harus memiliki rasa berkewajiban untuk maju bukan hanya karena kesukarelaan dalam memberikan pertanggungjawaban; dan

e. Harus dimungkinkan adanya perdebatan dan penilaian, termasuk penerapan sanksi oleh forum bukan sekedar monolog tanpa keterlibatan aktif masyarakat.

Untuk mewujudkan akuntabilitas anggota parlemen, ada beberapa kondisi yang harus dipenuhi. Pertama, tersedianya informasi untuk publik tentang berbagai aktivitas yang dilakukan oleh anggota parlemen. Kedua, kemampuan publik atau konstituen untuk bertanya kepada wakil-wakil mereka di parlemen terkait informasi tentang aktivitas mereka. Singkatnya, openness dan accessibility merupakan kunci penting untuk akuntabilitas anggota parlemen. Di mana openness diidentifikasi sebagai unsur pertama dari mekanisme kelola yang baik, dan digambarkan sebagai "proses dan informasi yang memungkinkan publik untuk melihat bagaimana lembaga bekerja dan berfungsi untuk memastikan bahwa informasi dapat diakses dan disebarkan secara luas kepada publik". Sedangkan Accesbility merupakan hak warga negara untuk memiliki akses tanpa hambatan ke informasi. Penyebaran luas informasi tentang kebijakan pemerintah demi membantu meningkatkan desain kebijakan, memfasilitasi penerimaan yang lebih luas dan mengamankan implementasi yang efisien (Rahman, 2007).

\section{Penyerapan Aspirasi Daerah}

Sesuai peraturan perundang-undangan, Anggota DPD RI wajib bertanggung jawab secara moral dan politis kepada konstituen di daerah pemilihannya sebagai bentuk dari akuntabilitas publik. Penyerapan aspirasi masyarakat dan daerah merupakan salah satu kegiatan Anggota DPD RI yang paling penting, karena kegiatan tersebut merupakan instrumen utama untuk memperjuangkan kepentingan masyarakat dan daerah. Untuk menentukan bagaimana penyerapan aspirasi dilakukan, tentu haruslah sesuai dengan ruang lingkup dan wewenang yang dimiliki setiap Anggota DPD RI, tanpa harus bergantung dengan sejauhmana daya jangkau yang diberikan. Berdasarkan ruang lingkup dan wewenang tersebut, maka dapat ditentukan dengan pihak mana saja relasi harus dijaga agar penyerapan aspirasi dapat optimal dilakukan.

Mengacu pada ketentuan Pasal 22D UUD 1945 dan Tata Tertib DPD RI, ruang lingkupnya adalah masalah yang terkait dengan otonomi daerah, hubungan pusat-daerah, pembentukan dan pemekaran serta penggabungan daerah, pengelolaan

99 https://doi.org/10.35308/ipp.v6i2.2400 sumber daya alam dan sumber daya ekonomi lainnya, serta perimbangan keuangan pusat dan daerah. Selain itu, ruang lingkup DPD RI juga meliputi masalah kesehatan, pendidikan, budaya dan agama.

Berdasarkan ruang lingkup urusan yang menjadi wewenang DPD RI tersebut, setiap Anggota DPD RI menjalin hubungan aspiratif dengan berbagai pihak, khususnya kementerian/lembaga di tingkat pusat dan pemerintah daerah, baik tingkat provinsi maupun kabupaten/kota. Oleh karena itu, hubungan aspiratif yang dijalin oleh Anggota DPD RI antara lain dengan:

a. Daerah sebagai satu kesatuan geografis dan lingkungan;

b. Masyarakat di daerah, terutama yang menjadi satu kesatuan hukum beserta alam dan lingkungannya;

c. Warga negara di daerah;

d. Pemerintah provinsi;

e. Pemerintah kabupaten/kota; dan

f. Organisasi sosial kemasyarakatan dan keagamaan.

Berbaga aspirasi dari berbagai daerah yang telah diserap oleh setiap Anggota DPD RI tentu harus disalurkan dan diperjuangkan dalam proses perumusan kebijakan nasional. Dengan demikian, Anggota DPD RI selalu eksis di dua tempat, yakni di ibu kota negara dan di daerah yang diwakilinya. Oleh karena itu, sudah sewajarnya dan seharusnya Anggota DPD RI bergerak aktif dari pusat ke daerah dan juga sebaliknya. Anggota DPD RI bukan sekadar berdomisili di daerah pemilihannya, tetapi juga mempunyai perangkat dan suber daya -berupa tenaga ahli dan staf administrasi pendukungyang dapat menggerakkan proses penyerapan aspirasi.

Oleh karena itu, DPD RI memiliki kantor perwakilan di setiap daerah pemilihan. Kantor inilah yang membantu Anggota DPD RI menyerap aspirasi dan menjaring informasi di tingkat daerah, lalu diolah, dikomunikasikan, lalu dirumuskan sebagai bahan dan rumusan kebijakan yang akan disalurkan dan diperjuangkan ke tingkat pusat. Dengan sistem dan mekanisme tersebut Anggota DPD RI dapat menjalankan fungsi representasinya sebagai wakil daerah secara maksimal. Berikut disajikan dalam gambar 2 tentang alur aspirasi DPD RI

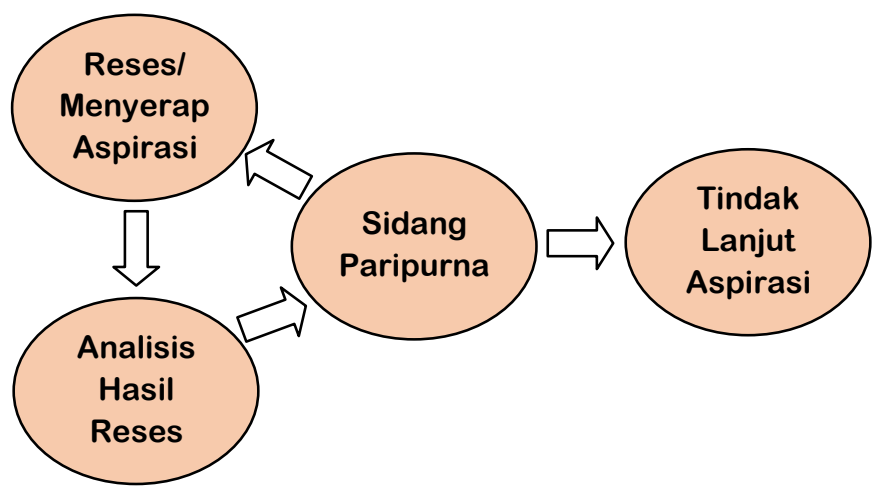

Gambar 2. Alur Aspirasi DPD RI (diolah berdasarkan Peraturan DPD RI Nomor 2 Tahun 2019 tentang Tata Tertib)

Bagan di atas menjelaskan bahwa Anggota DPD RI melakukan sidang paripurna sebelum melakukan reses atau kegiatan di daerah pemilihan, saat masa reses itulah anggota DPD RI melakukan penyerapan aspirasi di daerah. Setelah masa reses berakhir, Anggota DPD RI kembali melakukan sidang paripurna untuk melaporkan hasil penyerapan aspirasi yang 
telah dianalisis kepada Pimpinan DPD RI, selanjutnya aspirasi tersebut ditindaklanjuti.

\section{Tindak Lanjut Aspirasi Daerah: Program Layanan Kesehatan Gratis di Banten}

Pada saat reses atau kegiatan Anggota DPD RI di daerah pemilihan, Anggota DPD RI provinsi Banten menemukan permasalahan masyarakat Banten terkait program layanan kesehatan gratis. Program tersebut adalah program Pemerintah Provinsi Banten yang mana untuk biayanya menggunakan APBD Provinsi Banten. Akan tetapi, program layanan kesehatan gratis tersebut mendapatkan koreksi dari pemerintah pusat (Kementerian Kesehatan), sehingga belum dapat dilaksanakan karena masih dalam proses pengkajian dan koordinasi antara Kementerian Kesehatan RI dan BPJS karena ditengarai bertentangan dengan UU Nomor 24 Tahun 2011 tentang BPJS. Salah satu aspirasi masyarakat daerah Banten inilah yang dibawa dari daerah ke pusat untuk yang dilaporkan oleh Anggota DPD RI kepada pimpinan DPD RI.

Data dari Kementerian Kesehatan terkait program Jaminan Kesehatan Nasional (JKN)/Kartu Indonesia Sehat (KIS), secara nasional per April 2019, 75\% atau sekitar 196,2 juta jiwa telah terdaftar JKN-KIS, dan diharapkan pada tahun 2020 seluruh penduduk Indonesia dapat terdaftar. Sedangkan menurut data yang diambil dari pemerintah provinsi Banten, masyarakat Banten yang sudah terdaftar di JKN-KIS adalah sebanyak 8.435.816 jiwa (80,87\%), dengan rincian : Kabupaten Lebak 947.438, Kabupaten Pandeglang 871.106, Kabupaten Serang 1.061.452, Kabupaten Tangerang 2.249.321, Kota Cilegon 38.352, Kota Serang 357.202, Kota Tangerang 1.780.645, dan Kota Tangerang Selatan 785.132.

Tabel 1. Jumlah Penduduk Provinsi Banten yang Belum JKN

\begin{tabular}{llccc}
\hline \multirow{2}{*}{ No. } & Kabupaten/ & \multicolumn{3}{c}{ Belum JKN } \\
\cline { 2 - 5 } & Kota & PBI & PBPU & PPU \\
\hline 1. & Kab. Tangerang & 16,508 & 14,762 & 146,563 \\
2. & Kota Tangerang & 55,976 & 97,732 & 86,535 \\
3. & Kota Tangerang & 53,468 & 67,477 & 69,715 \\
& Selatan & & & \\
4. & Kab. Lebak & 141,469 & 47,863 & 87,293 \\
5. & Kab. Pandeglang & 168,291 & 3,883 & 91,018 \\
6. & Kab. Serang & 272,021 & 68,601 & 91,377 \\
7. & Kota Cilegon & 8,424 & 20,421 & 24,448 \\
8. & Kota Serang & 31,132 & 28,529 & 41,549 \\
\hline & $\quad$ Total & 895,861 & 517,073 & 638,497 \\
\hline
\end{tabular}

Sumber: Dinas Kesehatan Prov. Banten (2019)

Sedangkan dari tabel di atas, diketahui bahwa warga yang belum menjadi peserta JKN sebanyak 2.05l.431 jiwa, tersebar di 8 kabupaten/kota di Banten yang rencananya akan ditanggung Pemerintah Provinsi Banten untuk program layanan kesehatan berbasis e-KTP. Jumlah tersebut dibagi menjadi tiga kategori yaitu pekerja Penerima Bantun Iuran (PBI) sebesar 859.861 jiwa, Pekerja Bukan Penerima Upah (PBPU) sebesar 517.073 jiwa dan Penerima Upah (PPU) sebesar 638.497 jiwa.

Gambaran skema Jamkesda (program e-KTP) yang dikelola Pemprov Banten yakni sesuai visi Gubernur Banten dengan alur pelayanan sebagai berikut pada gambar 3 .

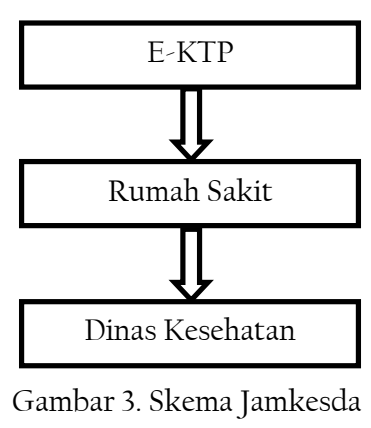

Maksud dari gambar di atas yaitu apabila masyarakat Povinsi Banten yang sudah mempunyai NIK mengalami sakit dan harus dirawat maka akan mendapatkan pelayanan rumah sakit yang telah ditunjuk. Kemudian pihak rumah sakit yang akan menagihkan klaim atau biaya pengobatan pasien kepada Dinas Kesehatan. Anggaran yang ditanggung oleh Pemerintah Provinsi Banten Tahun 2018 untuk pengobatan gratis berbasis e-KTP adalah 90 milyar, dana yang disiapkan untuk pembiayaan (premi) JKN-KIS sebesar 36 milyar, total dana yang disiapkan/dianggarkan sebesar 126 milyar dengan jenis penyakit yang ditanggung oleh Pemerintah Provinsi Banten adalah semua pelayanan yang tertera pada INA-CBG's

Rumah sakit yang melayani atau rumah sakit yang terintegrasi dengan pengobatan gratis berbasis e-KTP adalah semua rumah sakit yang terdapat di wilayah adminsitrasi Provinsi Banten. Sampai akhir 2018 kebijakan tersebut mengalami kendala belum dilaksanakan karena masih dalam tahap pengkajian dan konsultasi dengan Kementerian Kesehatan RI. Pada dasarnya, kebijakan Pemerintah Provinsi Banten terkait layanan kesehatan gratis bagi warga masyarakat yang belum masuk JKN-KIS sangat baik dan patut didukung sebagai upaya antisipasi hal-hal yang lebih buruk.

Dari hasil wawancara dengan beberapa pihak di Provinsi Banten memang banyak keluhan dari masyarakat terkait kejelasan program layanan kesehatan gratis. Banyak harapan masyarakat terkait program tersebut agar segera dapat dieksekusi. Dari temuan lapangan lainnya menunjukkan bahwa sebenarnya program tersebut sudah pernah dilaksanakan tetapi hanya di RSUD Banten di Kota Serang dan RSUD Malimping di Kabupaten Lebak yang lokasinya cukup jauh bagi yang masyarakat di luar daerah itu. Perbedaan program layanan kesehatan gratis ini dengan layanan JKN-KIS adalah cakupannya hanya untuk wilayah Banten dan tidak menggunakan sistem rujukan sehingga terkonsentrasi di rumah sakit yang ditunjuk berpotensi penuh dalam kasus tertentu.

Jika merujuk kepada Visi dan Misi Presiden Joko Widodo dalam Trisakti yaitu mandiri di bidang ekonomi, berdaulat di bidang politik, berkepribadian dalam kebudayaan, lalu dituangkan dalam 9 agenda prioritas nasional, salah satu agenda prioritas untuk Kementerian Kesehatan adalah meningkatkan kualitas hidup manusia Indonesia dengan tagline Program Indonesia Sehat melalui JKN-KIS. Menurut Menteri Kesehatan, pada rapat dengan Pimpinan DPD RI pada tanggal 17 Januari 2019, pihaknya menerima surat dari Gubernur Banten terkait program layanan kesehatan gratis untuk masyarakat Banten yang belum menjadi peserta JKN-KIS sebesar 2.051.431 jiwa, di mana jumlah tersebut diproyeksikan mampu ditanggung Pemerintah Provinsi Banten.

Menyikapi permasalahan tersebut, Anggota DPD RI Provinsi Banten melakukan koordinasi dan mediasi dengan 
Kementerian Kesehatan. Kemudian, Kementerian Kesehatan menyatakan bahwa pada intinya kebijakan tersebut merupakan kebijakan yang baik, namun perlu dikaji ulang dan perlu berkoordinasi dengan pihak-pihak terkait yakni Kementerian Keuangan, Kementerian Dalam Negeri, BPK serta kalau perlu KPK untuk mencegah ekses atau permasalahan hukum di kemudian hari, karena payung hukum yang dikhawatirkan dapat dijatuhi kepada kepala daerah apabila kebijakannya bertentangan dengan undang-undang yaitu pada UU Nomor 23 tahun 2014 tentang Pemerintah Daerah Pasal 68 yang menyatakan bahwa:

a. Kepala daerah dan atau wakil kepala daerah yang tidak melaksanakan program strategis nasional dikenai sanksi administratif berupa teguran tertulis oleh Menteri untuk Gubernur dan/atau wakil Gubernur serta oleh Gubernur sebagai Wakil Pemerintah Pusat untuk Bupati dan/atau Wakil Bupati atau Wali Kota dan/atau Wakil Wali Kota.

b. Teguran tertulis telah disampaikan 2 (dua) kali berturutturut dan tetap tidak dilaksanakan, kepala daerah dan/atau wakil Kepala daerah diberhentikan sementara selama 3 (tiga) bulan.

c. Kepala daerah dan/atau wakil kepala daerah telah selesai menjalani pemberhentian sementara, tetap tidak melaksanakan program strategis nasional, yang bersangkutan diberhentikan sebagai kepala daerah dan/atau wakil kepala daerah.

Dalam hal ini, DPD RI membuktikan akuntabilitasnya sebagai representasi daerah dalam menyelesaikan permasalahan di daerah dengan menindaklanjuti aspirasi daerah, melakukan peran atau fungsinya dalam pengawasan terhadap undangundang dan melaksanakan kewajibannya untuk menindaklanjuti aspirasi masyarakat dari daerah ke pusat. Hasil dari tindak lanjut itu, permasalahan program layanan kesehatan provinsi Banten telah menemukan solusi atau jalan tengah terbaik antara Kementerian Kesehatan, Pemerintah Provinsi Banten dan BPJS Kesehatan dengan adanya bentuk sinergi yang dilakukan yaitu dibagi 3 segmen:

a. Segmen PPU (potensi 638.497 jiwa) dengan menerbitkan regulasi kewajiban dan kewajiban badan usaha mendaftarkan seluruh karyawannya ke dalam JKN, sinergi pengawas dan petugas BPJS Kesehatan untuk penegakan kepatuhan dalam rangka melindungi kesehatan pekerja.

b. Segmen PBPU dan BP (potensi 460.983 jiwa) dengan mengeluarkan himbauan kepada penduduk yang mampu membayar iuran untuk melakukan pendaftaran sebagai peserta PBPU dan BP, mendorong pekerja sektor informasi untuk segera mendaftar JKN-KIS.

c. Segmen PBI (potensi 895.861 jiwa) dengan pendaftaran penduduk yang kurang mampu menjadi peserta PBI APBD, sharing iuran/peserta pemerintah provinsi dan pemerintah kabupaten/Kota.

Dari hasil tindak lanjut aspirasi tersebut, Anggota DPD RI Provinsi Banten menyatakan bahwa yang perlu dipahami dalam mengembangkan skema Jamkesda sendiri adalah dapat melengkapi skema jaminan kesehatan universal secara nasional. Di Indonesia, perkembangan Jamkesda bisa mengindikasikan beberapa kemungkinan dalam mewujudkan jaminan kesehatan universal, terutama dengan mengembangkan koordinasi terpadu antara pemerintah pusat dan pemerintah daerah. Dalam hal ini, pemerintah pusat merupakan "main organ" sistem kesehatan nasional dalam menyediakan cakupan esensial, khususnya bagi kelompok masyarakat miskin. Pemerintah daerah diperlukan untuk mengambil peran "auxiliary organ" dalam memberikan dukungan guna memastikan program tersebut sampai kepada penerima manfaat secara tepat dan cepat

\section{KESIMPULAN}

Keberhasilan akuntabilitas Anggota DPD RI tergantung pada kemampuan untuk menjalin hubungan yang sehat dengan lembaga kementerian atau eksekutif lainnya serta pemerintah daerah. Anggota DPD RI sebagai jembatan antara pusat dan daerah membawa aspirasi daerah provinsi Banten kasus program layanan kesehatan gratis masyarakat banten yang tidak dapat dilaksanakan karena mendapat koreksi dari Kementrian Kesehatan selaku pemerintah pusat yang mengurusi bidang kesehatan dengan alasan bertentangan dengan undang-undang yang berlaku. Akuntabiltas Anggota DPD RI terbukti dalam kasus ini karena Kementerian Kesehatan kini mendukung kebijakan Pemerintah Provinsi Banten tersebut untuk mengisi kekosongan sebelum seluruh masyarakat Banten terdaftar sebagai peserta JKN-KIS, namun dengan syarat bahwa Pemprov Banten terus mendaftarkan warganya dalam keikutsertaan JKN-KIS.

Berdasarkan pendekatan yang dilakukan oleh Anggota DPD RI, Pemerintah Provinsi Banten pun setuju untuk berkoordinasi/berkonsultasi dengan Kementerian Keuangan, Kementerian Dalam Negeri, BPK atau KPK untuk mencegah ekses atau permasalahan hukum dikemudian hari akibat kebijakan layanan kesehatan gratis berbasis e-KTP bagi warga masyarakat yang belum terdaftar peserta JKN-KIS. BPJS Kesehatan akan bersinergi dengan Pemerintah Provinsi Banten dengan mengoptimalisasikan pelaksanaan JKN-KIS diberbagai segmen peserta, termasuk mengintegrasikan penduduk dalam program e-KTP Provinsi Banten ke dalam kepesertaan JKNKIS.

Dengan adanya tindak lanjut dan peran serta Anggota DPD RI pada kasus di Banten tersebut, membuktikan adanya mekanisme akuntabilitas publik pada Anggota DPD RI. Peran Anggota DPD RI tetap sangat diperlukan sehingga daerahdaerah memiliki perwakilan yang terus memperjuangkan aspirasinya di level nasional

\section{REKOMENDASI}

1. Direkomendasikan kepada Anggota DPD RI, dalam rangka pencapaian akuntabilitas yang maksimal dalam menindaklanjuti aspirasi daerah, maka diperlukan langkahlangkah berikut:

a. Memperkuat akses anggota untuk hasil penelitian/pengkajian dan informasi terkait bidangnya;

b. Bermitra dan berkomunikasi dengan berbagai pihak dan mendorong partisipasi mereka dalam proses penyerapan aspirasi, misalnya dengan LSM, serikat pekerja, organisasi komunitas, dan organisasi keagamaan; dan

c. Memperkuat lembaga dan sistem komite dengan memperkuat kegiatan pengawasan;

d. Mengembangkan kapasitas staf anggota dalam melakukan analisis terhadap isu-isu strategis kepentingan nasional. 
2. Direkomendasikan kepada pemerintah daerah agar dapat melakukan pengintegrasian program Jaminan Kesehatan Daerah ke dalam Jaminan Kesehatan Nasional. Hal ini perlu diprtimbangkan agar pelaksanaan program-program kesehatan daerah dapat lebih berkesinambungan dan sejalan dengan program nasional, dan akhirnya cita-cita universal health coverage dapat segera tercapai dan bermanfaat secara tepat sehingga tidak terjadi rangkap jaminan.

\section{REFERENSI}

Cresswell, J. W. (2009). Research Design: Qualitative, Quantitative, and Mixed Methods Approaches. California: SAGE Publication.

Dahl, R. (1989). Democracy and its Critics. New Haven and London: Yale University Press.

Fuad, Z. M. (2017). Peran Peneliti dan Analis Kebijakan dalam Pembentukan Prolegnas dan RUU di Setjen DPD RI. Jurnal Wacana Kinerja, 201(1), 38.

Haque, M. S. (2000). Significance of Accountability Under the New Approach to Public Governance. SAGE Journals: International Review of Administrative Science, 66(4), 599-617. https://doi.org/https://doi.org/10.1177/0020852300664004

Hertanto, H. (2018). Tata Kelola Pemerintahan Daerah Otonom Baru pada Kabupaten Pesisir Barat, Provinsi Lampung. Journal of Government and Civil Society, 1(1), 81-93. https://doi.org/10.31000/jgcs.vlil.263

Heywood, A. (2000). Key Concepts in Politics. London: Palgrave Macmillan.

Manan, B. (1992). Perjalanan Historis Pasal 18 UUD 1945 (Perumusan dan Undang-Undang Pelaksanaannya). Jakarta: UNSIKA.

Mardiasmo. (2006). Perwujudan Transparansi dan Akuntabilitas Publik Melalui Akuntansi Sektor Publik: Suatu Sarana Good Governance. Jurnal Akuntansi Pemerintah, 2(1), 3 .

Morgenthau, H. J. (1973). Politics Among Nations: The Struggle for Power and Peace. New York: Alfred A. Knopf.

Napitupulu, P. (2007). Menuju Pemerintahan Perwakilan. Bandung: Alumni.

Pahlevi, I. (2014). Dinamika Sistem Pemilu Masa Transisi di Indonesia. Jurnal Politica, 5(2), 9 . https://doi.org/10.22212/jp.v5i2.339

Pitkin, H. F. (1967). The Concept of Representation. Berkeley, Los Angeles: University of California Press.

Puskada DPD RI. (2018). Hasil Pengolahan Aspirasi Masyarakat dan Daerah serta Rekomendasi Tindak Lanjut Pada Masa Kegiatan Anggota di Daerah Pemilihan Tahun 2018. Jakarta: Setjen DPD RI.

Rahman, T. (2007). Parliamentary Control and Government Accountability in South Asia: A Comparative Analysis of Bangladesh, India and Sri Lanka (Volume 6 de Routledge Advances in South Asian Studies). London: Routlodge. https://doi.org/https://doi.org/10.4324/9780203945766

Rasul, S. (2003). Pengintegrasian Sistem Akuntabilitas Kinerja dan Anggaran dalam Perspektif UU Nomor 17 Tahun 2003 tentang Keuangan Negara. Jakarta: PNRI.

Reiza Macella, A. D. (2020). Kinerja Organisasi Publik dalam Mendukung Penyelenggaraan Pelayanan di Kantor Kecamatan Johan Pahlawan. Jurnal Public Policy, 6(1), 51. https://doi.org/10.35308/jpp.v6il.1672
Sabourin, J. (2002). The Member of Parliament's Environment of Accountability. In n.a, Parliamentary Accountability and Good Governance: A Parliamentarian's Handbook. In Parliamentary Accountability and Good Governance: A Parliamentarian's Handbook (pp. 39-45).

Sanit, A. (1995). Perwakilan Politik di Indonesia. Jakarta: Rajawali.

Tjokroamidjojo, B. (1984). Pengantar Administrasi Pembangunan. Jakarta: LP3ES.

Trisna, N., \& Marefanda, N. (2018). Implementasi Akuntabilitas Terhadap Pengelolaan Anggaran di Dewan Perwakilan Rakyat Kabupaten Aceh Barat. Jurnal Public Policy, 3(1). https://doi.org/10.35308/jpp.v3il.160

Triwahyuni, M., Putera, R. E., \& Rahayu, W. K. (2020). Inovasi Pelayanan Kesehatan Kelas Imud Di Puskesmas Padang Pasir, Kecamatan Padang Barat, Kota Padang, Sumatera Barat. Jurnal Public Policy, 6(1), 13. https://doi.org/10.35308/jpp.v6il.1699

Turner, M. T., \& Hulme, D. (1997). Governance, Administration and Development: Making The State Work. London: MacMillan Press.

Victoria, A. O. (2019). Sri Mulyani Beberkan Empat Penyebab Defisit BPJS. 21 Agustus 2019.

Wulanadary, A., Sudarman, S., \& Ikhsan, I. (2019). Inovasi BPJS Kesehatan Dalam Pemberian Layanan Kepada Masyarakat: Aplikasi Mobile Jkn. Jurnal Public Policy, 5(2), 98. https://doi.org/10.35308/jpp.v5i2.1119

Undang-Undang Republik Indonesia Nomor 28 Tahun 1999 Penyelenggara Negara yang Bersih dan Bebas Dari Korupsi, Kolusi dan Nepotisme

Undang-Undang Republik Indonesia Nomor 40 Tahun 2004 tentang Sistem Jaminan Sosial Nasional

Undang-Undang Republik Indonesia Nomor 24 Tahun 2011 tentang Badan Penyelenggara Jaminan Sosial

Undang-Undang Republik Indonesia Nomor 23 Tahun 2014 tentang Pemerintahan daerah

Undang-Undang Republik Indonesia Nomor 2 Tahun 2018 tentang Perubahan Kedua atas Undang-Undang Nomor 17 Tahun 2014 tentang MPR, DPR, DPD dan DPRD

Peraturan Dewan Perwakilan Daerah Republik Indonesia Nomor 2 Tahun 2019 tentang Tata Tertib 